\title{
To assess mental health literacy among MBBS students about Psychiatric issues at Patna Medical College
}

\author{
Vivek Pratap Singh ${ }^{1}$, Kumar Satyadarshee ${ }^{2}$, Narendra Pratap Singh ${ }^{3}$ \\ ${ }^{1}$ Senior Resident, 2 Junior Resident, ${ }^{3}$ Professor and Head, Department of Psychiatry, Patna Medical College and \\ Hospital, Patna, Bihar, India
}

Background: Mental health is a big problem throughout the world, and India is not far behind. When we look at progress in the field of mental health, it appears to be sluggish. Despite the fact that a newly created mental health literacy (MHL) scale revealed substantial score disparities between the general public and mental health professionals, there is currently no published scale to measure MHL among healthcare students. Aims and Objectives: The major part was comparing the knowledge, attitude and perception of $1^{\text {st }}$ year medical students with final year medical students regarding psychiatric disorders and measuring there response on Likert scale. Materials and Methods: The participants were recruited from $1^{\text {st }}$ year to final year undergraduate students, during the period April 2019 to January 2020 in Patna Medical College and Hospital, Patna. The sample consisted of 100 students $\left(50\right.$ from $1^{\text {st }}$ year MBBS Students and 50 from final year MBBS (Students) Non-random, non-stratified, and purposive sampling was done for the purpose of the study. Results: Among the groups, majority of the of the final year students $(64 \%)$ agreed that the best described condition of the patient was Generalized Anxiety Disorder, but only $26 \%$ of the $1^{\text {st }}$ years students agreed that the best described condition of the patient was Generalized Anxiety Disorder. There was significant difference between $1^{\text {st }}$ years and final year students about the knowledge of the described condition with $\mathrm{P}<0.001$. Conclusion: Result showed that the final year students had more knowledge about the cases with regard to correct diagnosis, usefulness of various treatments and interventions and best the source of help. The $1^{\text {st }}$ and final year student had no differences in the attitude and perception regarding various cases given in the vignettes. Stigma based attitude was almost equally common among both $1^{\text {st }}$ year and final year students.

Key words: Health professionals and students; Medical education; Mental health literacy; Mental illness stigma; Public health education

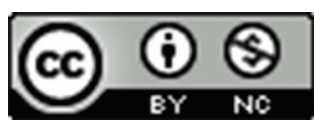

This work is licensed under a Creative Commons Attribution-NonCommercial 4.0 International License.

\section{INTRODUCTION}

Mental health is a big problem throughout the world, and India is not far behind. When we look at progress in the field of mental health, it appears to be sluggish. In 1954, Dr. Brock Chisholm, the first Director-General of the World Health Organization (WHO), predicted that "there can be no real physical health without mental health."1
Mental health is an important aspect of overall well-being. "Health is a condition of complete physical, mental, and social well-being, not just the absence of sickness or disability," according to the WHO constitution. This concept implies that mental health encompasses more than the absence of mental illnesses or impairments.

Mental health is a condition of well-being in which a person recognizes his or her own strengths, is able to cope with 
everyday pressures, works effectively, and contributes to his or her community. ${ }^{2}$

The capacity to get access to, comprehend, and apply information in ways that promote and sustain good health has been characterized as health literacy (HL).

The WHO extended the definition of HL in 1998 to include "the cognitive and social abilities that define an individual's motivation and ability to get, comprehend, and utilize information in ways that promote and sustain good health."”3

The mental health care delivery system has a difficulty due to a lack of understanding regarding mental illnesses. ${ }^{4} \mathrm{HL}$ and awareness are two sides of the same coin. Ignorance and misinformation have negative repercussions such as stigma and discrimination. ${ }^{4}$ In India, a research was conducted to assess mental health literacy (MHL). According to one research, teenage MHL is extremely poor, with just 29.04 percent of adolescents recognizing depression and only 1.31 percent recognizing schizophrenia/psychosis. Help-seeking was shown to be stigmatized. ${ }^{5}$

\section{Aims and objectives}

The objectives are as follows:

- To assess knowledge among the medical students about Depression, Schizophrenia, Generalized anxiety disorder, and OCD.

- To assess the attitude and perception among the medical students about the treatment and outcome of depression, Schizophrenia, generalized anxiety disorder, and OCD.

- To compare the knowledge, attitude and perception of $1^{\text {st }}$ year medical students with final year medical students regarding cases of depression, schizophrenia, generalized anxiety disorder, and OCD.

\section{MATERIALS AND METHODS}

\section{Study design}

It was a cross-sectional hospital based study.

\section{Study time}

The study period was January 2020 to June 2020.

\section{Study population}

The participants were recruited from $1^{\text {st }}$ year to final year undergraduate students, Patna Medical College and Hospital, Patna.

\section{Sample size}

The sample consisted of 100 students (50 from $1^{\text {st }}$ year MBBS Students and 50 from final year MBBS students).

\section{Sampling technique}

Non-random, non-stratified, and purposive sampling were done for the purpose of the study.

\section{Inclusion criteria}

The following criteria were included in the study:

1. Age $17-25$ years of age.

2. Either Gender.

3. Willing to give informed consent for the study.

4. First and final year MBBS students.

\section{Exclusion criteria}

The following criteria were excluded from the study:

1. The presence of any psychiatric disorder.

2. History of chronic physical disease.

3. Not willing for participation.

\section{Tools of assessment}

\section{Semi-structured socio-demographic pro forma}

A pro forma was developed to obtain sociodemographic variables such as age, sex, marital status, education, occupation, religion, and residence.

\section{Vignettes for depression, anxiety disorder and other psychiatric disorders}

The participants were given vignettes and self-administered questionnaires related to the vignettes and the responses measured on Likert scale.

Example:-

\section{Vignette 1}

Rita is 32-years-old, married female, works full-time for a computer company, and is currently enrolled in classes at a local college. She complains of dizziness, heart palpitations, ringing ears, trembling, and sweating palms. Additional periodic symptoms include a sore throat, cough, or dry mouth and throat. Periods of extreme muscle tension, along with feelings of being "wound up" or "edgy" are also present. These symptoms often interfere with her concentration and have been present more often than not for about the past 2 years. Rita constantly worries about failing her classes, completing projects at work in a timely manner, being able to please his parents and husband, and paying bills. She keeps a low profile at work, and also avoids going out with friends, meeting new people.

\section{Vignette 2}

Ravi is 32-years-old. He has been feeling unusually sad and miserable for the last few weeks. Even though he is tired all the time, he has trouble sleeping nearly every night. He doesn't feel like eating and has lost weight. He doesn't take bath regularly or groom himself. He does not want to interact with people. He can't keep his mind on his work and puts off making any decisions. Even day-to-day tasks 
seem too much for him. He feels like his time is passing very slowly. This has come to the attention of Ravi's boss who is concerned about his low productivity. Ravi feels he will never be happy again and believes his family would be better off without him. He feels worthless. Ravi has been so desperate, he has been thinking of ways to end his life.

\section{Methodology}

A written informed consent was obtained for participation after explaining the purpose and design of the study. The participants were chosen among the $1^{\text {st }}$ year and final year MBBS students by applying inclusion and exclusion criteria. The study tools were applied subsequently. A total of 100 participants 50 from $1^{\text {st }}$ year MBBS students and 50 final year MBBS students were taken for this study. After the data was obtained, statistical analysis was done using Chi-square test and independent $\mathrm{t}$-test to compare the two groups with respect to insight and other variables.

\section{RESULTS}

Table 1 depicted the gender-wise distribution of study population. It has been observed from the study that majority of the patients in the study were males (61\%). About $39 \%$ of patients were female, which indicated adequate gender-wise distribution of study population. In Figure 1, pie diagram showing majority of patients were male $(61 \%)$.

Table 2 shows the mean age (years) of the $1^{\text {st }}$ and final year students. First year students, group had average age of 19.76 years; whereas the final year students, group had average age of 24.06 years.

In this study, the majority of the respondents belong to Hindu community $(85 \%)$ and from middle class background $(72 \%)$ (Table 3$)$.

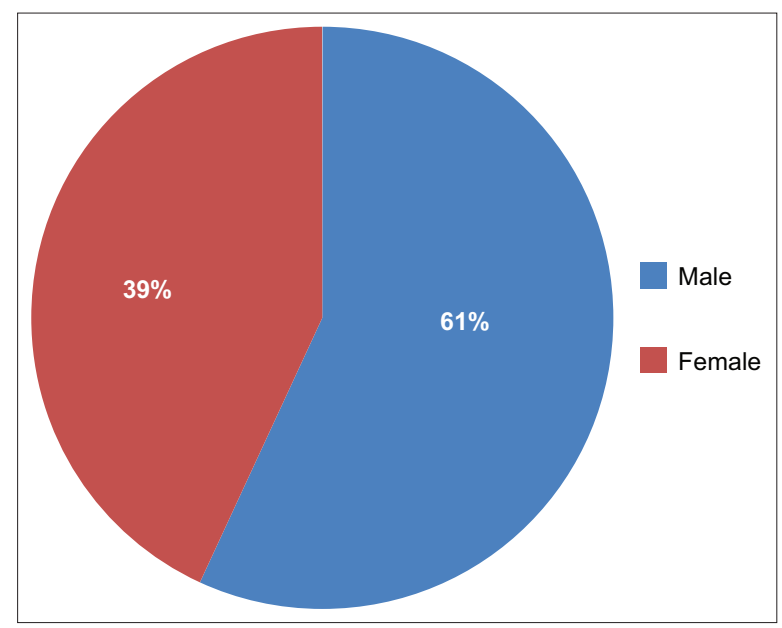

Figure 1: Pie diagram showing distribution of age-distribution
Table 4 shows that out of 100 respondents, the majority of the students $(45 \%)$ agreed that the best describe

\begin{tabular}{lcc}
$\begin{array}{l}\text { Table 1: Gender-wise distribution of study } \\
\text { population }\end{array}$ & \\
\hline Gender & Frequency & Percentage \\
\hline Male & 61 & 61.0 \\
Female & 39 & 39.0 \\
Total & 100 & 100.0 \\
\hline
\end{tabular}

\begin{tabular}{lcc}
\multicolumn{3}{l}{ Table 2: Mean age of study population } \\
Age & First year & Final year \\
\hline Mean \pm SD & $19.76 \pm 1.62$ & $24.06 \pm 0.98$ \\
Total & 50 & 50 \\
\hline
\end{tabular}

\begin{tabular}{|c|c|c|}
\hline & Frequency & Percent \\
\hline \multicolumn{3}{|l|}{ Religion } \\
\hline Hindu & 85 & 85.0 \\
\hline Muslim & 13 & 13.0 \\
\hline Christian & 2 & 2.0 \\
\hline \multicolumn{3}{|c|}{ Socioeconomic status } \\
\hline High class & 19 & 19.0 \\
\hline Lower class & 8 & 8.0 \\
\hline Middle class & 72 & 72.0 \\
\hline Upper class & 1 & 1.0 \\
\hline Total & 100 & 100.0 \\
\hline
\end{tabular}

\begin{tabular}{|c|c|c|c|c|}
\hline \multirow{2}{*}{$\begin{array}{l}\text { Best describe } \\
\text { what is wrong } \\
\text { with the patient? }\end{array}$} & \multirow[t]{2}{*}{ Total } & \multicolumn{2}{|c|}{ Education } & \multirow[t]{2}{*}{ P-value } \\
\hline & & $\begin{array}{l}\text { First } \\
\text { years }\end{array}$ & $\begin{array}{l}\text { Final } \\
\text { year }\end{array}$ & \\
\hline Adjustment & 3 & 1 & 2 & $0.001^{* *}$ \\
\hline Disorder & $3.00 \%$ & $2.00 \%$ & $4.00 \%$ & \\
\hline Attention Deficit & 17 & 11 & 6 & \\
\hline $\begin{array}{l}\text { Hyperactivity } \\
\text { Disorder }\end{array}$ & $17.00 \%$ & $22.00 \%$ & $12.00 \%$ & \\
\hline Cancer & $\begin{array}{c}3 \\
3.00 \%\end{array}$ & $\begin{array}{c}3 \\
6.00 \%\end{array}$ & $\begin{array}{c}0 \\
0.00 \%\end{array}$ & \\
\hline Generalized & 45 & 13 & 32 & \\
\hline Anxiety Disorder & $45.00 \%$ & $26.00 \%$ & $64.00 \%$ & \\
\hline Heart Attack & $\begin{array}{c}7 \\
7.00 \%\end{array}$ & $\begin{array}{c}5 \\
10.00 \%\end{array}$ & $\begin{array}{c}2 \\
4.00 \%\end{array}$ & \\
\hline Major Depression & $\begin{array}{c}3 \\
3.00 \%\end{array}$ & $\begin{array}{c}0 \\
0.00 \%\end{array}$ & $\begin{array}{c}3 \\
6.00 \%\end{array}$ & \\
\hline Panic disorder & $\begin{array}{c}12 \\
12.00 \%\end{array}$ & $\begin{array}{c}10 \\
20.00 \%\end{array}$ & $\begin{array}{c}2 \\
4.00 \%\end{array}$ & \\
\hline $\begin{array}{l}\text { Psychological/ } \\
\text { mental/emotional } \\
\text { problems }\end{array}$ & $\begin{array}{c}5 \\
5.00 \%\end{array}$ & $\begin{array}{c}4 \\
8.00 \%\end{array}$ & $\begin{array}{c}1 \\
2.00 \%\end{array}$ & \\
\hline Schizophrenia & $\begin{array}{c}2 \\
2.00 \%\end{array}$ & $\begin{array}{c}0 \\
0.00 \%\end{array}$ & $\begin{array}{c}2 \\
4.00 \%\end{array}$ & \\
\hline $\begin{array}{l}\text { Obsessive } \\
\text { compulsive } \\
\text { Disorder }\end{array}$ & $\begin{array}{c}3 \\
3.00 \%\end{array}$ & $\begin{array}{c}3 \\
6.00 \%\end{array}$ & $\begin{array}{c}0 \\
0.00 \%\end{array}$ & \\
\hline Total & $\begin{array}{c}100 \\
100.00 \%\end{array}$ & $\begin{array}{c}50 \\
100.00 \%\end{array}$ & $\begin{array}{c}50 \\
100.00 \%\end{array}$ & \\
\hline
\end{tabular}


condition of the patient was Generalized Anxiety Disorder, $3 \%$ agreed that the described condition was adjustment disorder, $17 \%$ believed that the condition is best described as "Attention Deficit Hyperactivity Disorder", 3\% thought cancer, 7\% thought it was Heart Attack, 3\% agreed Major Depression, $12 \%$ answered Panic disorder, 5\% answered Psychological/mental/emotional problems, $2 \%$ answered and Schizophrenia, 3\% Obsessive compulsive disorder.

Among the groups, the majority of the of the final year students $(64 \%)$ agreed that the best described condition of the patient was Generalized Anxiety Disorder, but only $26 \%$ of the $1^{\text {st }}$ years students agreed that the best described condition of the patient was Generalized Anxiety Disorder. There was significant difference between $1^{\text {st }}$ year and final year students about the knowledge of the described condition with $\mathrm{P}<0.001$.

Table 5 shows that the mean score of "People with a problem like his/hers usually get better on their own" and "A problem like this is a sign of personal weakness" as belief was found to be significantly higher in $1^{\text {st }}$ year students as compared to final year students $(\mathrm{P}=0.001)$. However, a majority of both $1^{\text {st }}$ year $($ mean $=3.04)$ and final year students $($ mean $=3.50)$ believed that the patient mentioned in the case can be dangerous to themselves and others.

Table 6 shows that out of 100 respondents, 3\% didn't know about the outcome if the patient does not receive professional help, $46 \%$ believed that the her $/$ his problems would get worse if the patient does not receive professional help, $19 \%$ agreed no improvement in her/his problems if the patient does not receive professional help, $16 \%$ believed partial recovery if the patient does not receive professional help, 16\% thought full recovery/but problems would probably recur if the patient does not receive professional help and only 16\% agreed to have full recovery/but problems would probably recur if the patient does not receive professional help.

Among the groups, the majority of the of the final year students $(58 \%)$ agreed that her/his problems would get worse if the patient does not receive professional help, but only $34 \%$ of the $1^{\text {st }}$ years students agreed that her/his problems would get worse if the patient does not receive professional help. There was no significant difference between $1^{\text {st }}$ year and final year students with $\mathrm{P}>0.05$.

\section{DISCUSSION}

The average age of $1^{\text {st }}$-year students in this study was 19.76 \pm 1.62 , whereas the average age of final-year students was $24.06 \pm 0.98$.

\begin{tabular}{|c|c|c|c|}
\hline Belief about this case & First years & Final year & P-values \\
\hline \multicolumn{4}{|l|}{$\begin{array}{l}\text { People with a problem } \\
\text { like his/hers usually get } \\
\text { better on their own }\end{array}$} \\
\hline Mean & 2.92 & 1.56 & $0.001^{* *}$ \\
\hline SD & \pm 1.01 & 0.97 & \\
\hline \multicolumn{4}{|l|}{$\begin{array}{l}\text { A problem like this } \\
\text { is a sign of personal } \\
\text { weakness }\end{array}$} \\
\hline Mean & 2.70 & 1.56 & $0.001^{* *}$ \\
\hline SD & \pm 0.97 & 0.70 & \\
\hline \multicolumn{4}{|l|}{$\begin{array}{l}\text { Can be dangerous to } \\
\text { themselves or others }\end{array}$} \\
\hline Mean & 3.04 & 3.50 & 0.061 \\
\hline SD & \pm 1.32 & 1.09 & \\
\hline \multicolumn{4}{|l|}{$\begin{array}{l}\text { If I had a problem like } \\
\text { his/hers, I would not tell } \\
\text { anyone }\end{array}$} \\
\hline Mean & 1.98 & 2.24 & 0.266 \\
\hline SD & \pm 0.96 & 1.33 & \\
\hline \multicolumn{4}{|l|}{$\begin{array}{l}\text { I would not employ } \\
\text { someone if I knew they } \\
\text { had a problem like him/ } \\
\text { her }\end{array}$} \\
\hline Mean & 1.76 & 1.68 & 0.632 \\
\hline SD & \pm 0.96 & 0.68 & \\
\hline \multicolumn{4}{|l|}{$\begin{array}{l}\text { I would not be friends } \\
\text { with someone if I knew } \\
\text { they had a problem like } \\
\text { him/her }\end{array}$} \\
\hline Mean & 1.46 & 1.30 & 0.195 \\
\hline SD & \pm 0.73 & 0.46 & \\
\hline \multicolumn{4}{|l|}{$\begin{array}{l}\text { People with a problem } \\
\text { like hers/his will be } \\
\text { discriminated against } \\
\text { by others in the } \\
\text { community had a } \\
\text { problem like him/her }\end{array}$} \\
\hline Mean & 1.94 & 1.92 & 0.927 \\
\hline SD & \pm 0.84 & 1.29 & \\
\hline
\end{tabular}

\begin{tabular}{lcccc}
$\begin{array}{l}\text { Table 6: The responses of the students to } \\
\text { question "F" of Vignette 2. } \\
\text { qutcome if the }\end{array}$ & Total & $\begin{array}{c}\text { First } \\
\text { years }\end{array}$ & $\begin{array}{c}\text { Final } \\
\text { year }\end{array}$ & P-value \\
$\begin{array}{l}\text { Outient does not } \\
\text { paceive professional } \\
\text { recelv }\end{array}$ & & & & \\
help & 3 & 3 & 0 & 0.065 \\
\hline Don't know & $3.0 \%$ & $6.0 \%$ & $0.0 \%$ & \\
& 46 & 17 & 29 & \\
Her/his problems & $46.0 \%$ & $34.0 \%$ & $58.0 \%$ & \\
would get worse & 19 & 11 & 8 & \\
No improvement in & $19.0 \%$ & $22.0 \%$ & $16.0 \%$ & \\
her/his problems & 16 & 11 & 5 & \\
Partial recovery & $16.0 \%$ & $22.0 \%$ & $10.0 \%$ & \\
& 16 & 8 & 8 & \\
Full recovery/but & $16.0 \%$ & $16.0 \%$ & $16.0 \%$ & \\
problems would & & & & \\
probably recur & 0 & 0 & 0 & \\
Full recovery with no & 0 & 0 & 0 & \\
relapse & 100 & 50 & 50 & \\
Total & $100.0 \%$ & $100.0 \%$ & $100.0 \%$ & \\
& & & & \\
\hline
\end{tabular}


In a similar research, between April and June 2018, a questionnaire was given to students over the age of 20 at 11 universities among Taiwan with departments of medicine and public health to measure MHL in healthcare students. ${ }^{6}$

The present study consisted of 61 male and 39 female students. In this research, the Hindu community accounted for the bulk of respondents (85\%), followed by Muslims $(13 \%)$, and Christians (2\%). This conclusion is compatible with the fact that Hinduism is the state's primary religion, with 82.7 percent of the entire population practicing it according to the 2011 census report. $^{7}$

In vignette 1 , the majority of final-year students (64\%) could properly identify the condition of Generalized Anxiety Disorder, whereas just $26 \%$ of $1^{\text {st }}$-year students could. With $\mathrm{P}=0.001$, there was a substantial difference in understanding of the specified condition between $1^{\text {st }}$ and final year students.

Overall, final-year students were able to accurately diagnose the case situations provided to them in the vignettes, but the majority of $1^{\text {st }}$-year students were unable to do so. This conclusion is in line with those of previous studies. ${ }^{8}$

Seeing a psychiatrist was the most popular response for "Best" source of aid across all four scenarios. However, a significant proportion of $1^{\text {st }}$-year students sought psychological assistance. Other sources of support, other from psychiatrists, were likewise approved more by $1^{\text {st }}$-year students than by final-year students. Students in their last year were much more likely to recommend seeking psychiatric treatment (vs. informal support) and psychiatric sources (vs. medical aid, such as a doctor/GP). This association is not surprising, because it is most likely the outcome of training and course curricula, as well as exposure to and experience working with persons with mental illnesses. The inclination to seek help from informal sources declined with age 64 , according to a MHL research conducted among university students in Australia.

Psychiatrists found similar results in a previous study on MHL in relation to depression, mania, and schizophrenia.? students endorsed anti-anxiety for GAD, attending support therapy for depression, anti-anxiety for schizophrenia, and support therapy for OCD. This might be because the majority of $1^{\text {st }}$-year students unable to diagnose the case scenarios in the vignettes. However, even after a proper diagnosis, a significant proportion of $1^{\text {st }}$-year students choose the incorrect medications/interventions, which might be related to the fact that they are not introduced to pharmacology in their academic curriculum in $1^{\text {st }}$ year.

The majority of patients in all four vignettes felt that the patients "Can be hazardous to themselves or others," particularly among patients with schizophrenia and depression.

"People with a problem like his/hers normally get better on their own," People having a problem like hers/his will be discriminated against by others in the community had a problem like him/her. In the situations of depression and OCD, $1^{\text {st }}$-year students agreed that "people with similar problems normally get well on their own," whereas in the case of schizophrenia, final-year students agreed that "people with similar problems will be discriminated against by others in the community."

Both $1^{\text {st }}$-year and final-year students exhibit a negative and stigmatizing attitude toward mental health disorders, according to the findings. In a comparable research of $1^{\text {st }}$ and final year students to determine the stigma associated with schizophrenia, it was discovered that final year students with awareness of mental disease had a lower likelihood of having a negative attitude about mental health problems. These same people who had past interaction with the mentally ill were also more accepting and thought the mentally ill were less hazardous. $1^{\text {st }}$-year students who were unfamiliar with mental illness tended to regard the mentally ill as more hazardous and felt that a greater social distance should be maintained from the target individual. ${ }^{10}$

The most popular responses to the illness's fate if not treated were "Her/his difficulties will become worse," "No improvement in her/his problems," and "Partial recovery" across all four vignettes. The majority of people in Singapore ${ }^{11}$ and Australia ${ }^{12,13}$ said the individual in the vignette would become worse, and the responses to this question matched those of the broader public in both countries.

\section{Limitations of the study}

The current study had the undermentioned limitations-

1. A study with a larger sample size would have yielded much better result.

2. The study did not compare the knowledge, attitude and perception about mental health problems between male and female students.

\section{CONCLUSION}

The present study was conducted in Patna Medical College, Patna, Bihar, with the aim to assess the MHL among the MBBS students about depression, schizophrenia, generalized anxiety disorder, and obsessive compulsive disorder. Result showed that the final year students had more knowledge about the cases with regards to correct diagnosis, usefulness of various treatments and interventions and best the source of help. 
The $1^{\text {st }}$ and final year student had no differences in the attitude and perception regarding various cases given in the vignettes.

Stigma based attitude was almost equally common among both $1^{\text {st }}$ year and final year students.

\section{ACKNOWLEDGMENT}

The authors take this opportunity to thank the Department of Psychiatry for their whole hearted support for this study.

\section{REFERENCES}

1. Kolappa K, Henderson DC and Kishore SP. No physical health without mental health: Lessons unlearned? Bull World Health Organ. 2013;91(1):3-3A.

http://dx.doi.org/10.1371/journal.pone.0214916

2. Available from: https://www.who.int/news-room/fact-sheets/ detail/mental-health-strengthening-our-response" mentalhealth-strengthening-our-response-2018;3; https://www.who.int/ news-room/fact-sheets/detail/mental-health-strengthening-ourresponse. [Last accessed on 2021 Oct 07].

3. Kanj M and Mitic W. Working Document: $7^{\text {th }}$ Global Conference on Health Promotion, Promoting Health and Development: Closing the Implementation Gap. Nairobi, Kenya, 26-30 October 2009. Geneva, CH: World Health Organization; 2009.

https://doi.org/10.1177/0706743715616609

4. Brown VA, Harris JA and Russell JY. Tackling Wicked Problems through the Transdisciplinary Imagination. London: Earthscan; 2010. https://dx.doi.org/10.4103_45_17

5. Ogorchukwu JM, Sekaran VC, Nair S and Ashok L. Mental health literacy among late adolescents in South India: What they know and what attitudes drive them. Indian J Psychol Med. 2016;38(3):234-241.

https://doi.org/10.1111/j.1751-7893.2008.00085.x

6. Chao HJ, Lien YJ, Kao YC, Tasi IC, Lin HS and Lien YY. Mental health literacy in healthcare students: An expansion of the mental health literacy scale. Int J Environ Res Public Health. 2020;17(3):948.

https://doi.org/10.3390/ijerph17030948
7. Office of the Registrar General and Census Commissioner, India. Ministry of Home Affairs, Government of India; 2011. Available from: https://r.search.yahoo.com/ ylt=AwrwJSfi61FhzwUANhG7HAx.;_ylu=Y29sbwNzZzME cG9zAzIEdnRpZAMEc2VjA3Ny/RV=2/RE $=1632787554 /$

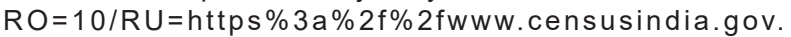
in $\% 2$ f2011-common\%2faboutus.html/RK=2/RS=tkn. yVyiho7hLY3wwwDuqs3NWqA-. [Last accessed on 2021 Oct 07].

8. Kethawath SM, Pingali S, Kante SK and Molangur U. Mental health literacy about depression among medical students at a tertiary care hospital in South India. Telangana J Psychiatry. 2020:6(1):9-13.

http://dx.doi.org/10.18231/j.tjp.2020.004

9. Parker G, Mahendran R, Yeo SG, Loh MI and Jorm AF. Diagnosis and treatment of mental disorders: A survey of Singapore mental health professionals. Soc Psychiatry Psychiatr Epidemiol. 1999;34(10):555-563.

http://dx.doi.org/10.1007/s001270050175 Available from: http://gateway.webofknowledge.com/gateway/Gateway. cgi?GWVersion=2 and SrcApp=PARTNER_APP and SrcAuth=LinksAMR and KeyUT=WOS:000315688800001 and DestLinkType=FullRecord and DestApp=ALL_WOS and Usr CustomerID=891bb5ab6ba270e68a29b250adbe88d1. [Last accessed on 2021 Oct 07].

10. Mas A and Hatim A. Stigma in mental illness: Attitudes of medical students towards mental illness. Med J Malaysia. 2002;57(4):433-444.

https://doi.org/10.1176/appi.ps.20120p836

11. Picco L, Abdin E, Chong SA, Pang S, Vaingankar JA, Sagayadevan V, et al. Beliefs about help seeking for mental disorders: Findings from a mental health literacy study in Singapore. Psychiatr Serv. 2016;67(11):1246-1253.

https://doi.org/10.1080/00981389.2017.1383335

12. Reavley NJ and Jorm AF. National Survey of Mental Health Literacy and Stigma. Canberra, Australia: Department of Health and Ageing; 2011a.

https://dx.doi.org/10.18203/2394-6040.ijcmph20192350

13. Reavley NJ and Jorm AF. Recognition of mental disorders and beliefs about treatment and outcome: Findings from an Australian National Survey of Mental Health Literacy and Stigma. Aust N Z J Psychiatry. 2011b;45(11):947-956.

https://doi.org/10.1016/j.jad.2012.11.014

\footnotetext{
Authors Contribution:

VPS- Concept and design of the study; prepared first draft of manuscript; KS- Interpreted the results; reviewed the literature and manuscript preparation, statistical analysis and interpretation, preparation of manuscript and revision of the manuscript; NPS- Concept, coordination, review of literature and manuscript preparation

Work attributed to:

Patna Medical College and Hospital, Patna, Bihar, India

Orcid ID:

Dr. Vivek Pratap Singh - (D) https://orcid.org/0000-0002-6780-2484

Dr. Kumar Satyadarshee - (D) https://orcid.org/0000-0002-6343-1495

Dr. Narendra Pratap Singh - (1) https://orcid.org/0000-0002-6997-5311

Source of Funding: None, Conflicts of Interest: None.
} 